\title{
African colonial soldiers, memories and imagining migration in Senegal in the twenty-first century
}

\author{
Martin Mourre
}

In 1996, for several months, African immigrants in France occupied the SaintBernard church in the 18th arrondissement of the French capital. ${ }^{1}$ These men and women, who initially lacked resources, succeeded in gaining support among a sector of the public for their demands for the administrative regularization of their situation (Blin 2005). Among the arguments they put forward, one was rooted in a common history shared between two spaces, Africa and France. More precisely, these 'sans papiers' (people without papers or ID) felt that it was necessary to draw on the history of the African soldiers recruited into the French army in the nineteenth and twentieth centuries, known under the generic name of Senegalese tirailleurs. ${ }^{2}$ This argument of the 'blood debt', which emerged at the end of World War One, had particular echoes in West Africa. ${ }^{3}$ Another anecdote shows how the issue of migration is interwoven with a similar colonial past, this time on the other side of the Mediterranean. From 2006 onwards, the news has been dominated by the tragic departure of thousands of young Africans trying to leave the continent in the hope of a better life, and Senegal became one of the 'hubs' of this immigration, in particular on its coasts, where migrants embarked on pirogues, especially from a village on the outskirts of Dakar called Thiaroye-sur-Mer. The Socialist Party candidate in the French presidential elections in 2007, Ségolène Royal, who was level pegging in the race to be head of state, travelled to this village to discuss the question of migration and to support the mothers of families, some of whom had lost a son during the sea crossing to Europe. Following this visit, the village of Thiaroyesur-Mer became one of the symbols of this informal immigration (Bouilly 2008). Three years later, Royal again visited this suburb of Dakar. The speech she made on this occasion was largely a response to the speech given by President Sarkozy in 2007 at Cheikh Anta Diop University and deemed by

\footnotetext{
Martin Mourre is a postdoctoral researcher attached to the German Historical Institute and to the Centre de Recherche sur les Politiques Sociales (CREPOS). He is based in Dakar, where he is researching former soldiers from 1945 to 1975. Email: martinmourre@hotmail.com

This article was translated from the French by Andrew Brown. The original French version is available as supplementary material with the online version of this article. See <https://doi.org/ 10.1017/S0001972018000207>.

${ }^{1}$ The Saint-Bernard church is located in the Goutte d'Or district in Paris, an ethnically mixed area whose population comes largely from the Maghreb, West Africa and Central Africa.

${ }^{2}$ The Senegalese tirailleurs (infantrymen) were African soldiers recruited by France and constituted as a military corps in 1857 at the request of Louis Faidherbe. These men were mainly from the territories of French West Africa. The word 'tirailleur' used for the Senegalese gradually became more widely accepted and has been a generic term from the beginning of the twentieth century. Two important studies on these men are Echenberg (1991) and Mann (2006).

${ }^{3}$ See the particularly significant work by the Malian historian Bakary Kamian (2001).
} 
several commentators to be insulting to Africans (Ba Konaré 2009; Chrétien 2008). ${ }^{4}$ It referred to a drama in colonial history that has left a particularly vivid imprint in Senegal, although it is all but unknown in France: the Thiaroye massacre. In 1944, in this village, home to one of the largest military camps in French West Africa, there was a massacre of Senegalese tirailleurs who had returned from Europe and were slaughtered by their French superiors for demanding their war-time salaries. ${ }^{5}$ In today's Senegal, this drama has become one of the most eloquent symbols of colonial injustice (Mourre 2017a).

These two anecdotes, involving West African migrants and the international agenda of one French politician, Ségolène Royal, show that even several decades after independence, the history of the tirailleurs, on different levels, is still an element in a common language shared by France and West Africa. They reveal a collective memory in constant evolution. This language, which feeds into many aspects of public life, is deployed by different actors, but what seems to guarantee its effectiveness is that it is integrated into the imaginaires of both France and Senegal. Following the arguments developed by Cornelius Castoriadis in his book The Imaginary Institution of Society (1987), this article is an attempt to reconsider the representations that, in Senegal in the 2000s, linked the social history of the tirailleurs with the practical and symbolic processes at the heart of a number of migratory projects, especially among young people. From this point of view, the imaginaire, 'active as such, is situated at a level different from any functional determination' (ibid.: 130). For Castoriadis, whose perspective seeks to go beyond a structural-Marxist understanding of the social, the individual unconscious as rooted in a collective 'social-historical' lies at the heart of the analysis: 'what holds a society together is the holding-together of its world of significations' (ibid.: 359). Focusing on the memories of the African fighters of the French Empire thus means taking on board notions such as honour, courage and suffering, which today constitute powerful binding forces in the representations of the imaginaire of migration in Senegal. These representations always produce definite effects. In the mid-2000s, a slogan was attributed to the young people of Senegal: 'Barça or Barzakh [barsaq]' - that is, see Barcelona (Barça being the local football club, a metonym of Europe), or die (Barzakh meaning 'the next world' in Wolof). Death was thus preferred to the social shame of staying in the country, without any future. However, I argue that, in addition to socio-economic factors, the different strata relating to Franco-African and Senegalese collective history must be integrated in any analysis of these migrations of despair.

In the first part of this article, I show how, for a period of over eighty years, from the end of World War One, a discourse on the 'blood debt' was developed. This

\footnotetext{
${ }^{4}$ It was in this speech that Nicolas Sarkozy, elected in 2007 , uttered a sentence that was widely interpreted as marking a resurgence of essentialist prejudices about Africa. He said that 'the drama of Africa [was that] African man has not sufficiently entered history'. Moreover, it should be noted that, in metropolitan France, the years of the Sarkozy presidency were marked by a series of declarations aimed against immigrant communities, the framework of the debate being an 'immigration that was chosen' as opposed to an 'immigration that was endured'.

${ }^{5}$ There is some uncertainty over the actual number of fatalities; the figure of thirty-five deaths often put forward in the colonial archives seems an underestimate. The exact place where the tirailleurs were buried is also controversial. For further information on this brutal repression, see Mourre (2017a).
} 
language of reciprocity and obligation, however asymmetrical, was articulated by the French state and its veterans but also by an entire group of political actors, both French and Senegalese. ${ }^{6}$ Moreover, after the arrival of Abdoulaye Wade in 2000 , the figure of the tirailleur was widely drawn on in Senegalese public space, especially because of the tragedy of Thiaroye. The memorializing policies of the Senegalese state led it to construct an image of the tirailleur that triggered a new process, shaped by the binary 'hero-victim'. This process was concomitant with the emergence of another figure in Senegalese society: the migrant. This figure took shape more clearly after independence, just as 'Senegalese tirailleurs' were disappearing as a social body. By bringing together colonial and postcolonial temporality, a study of how these representations were constructed may help us better understand some of the bases of the 'imagined community' (Anderson $2016)^{7}$ in Senegal. In the second part, I trace the ways in which studies on migration in France and Senegal have gradually shifted towards a focus on the subjectivities of the actors, mainly on the basis of bibliographical details. In the third part, I first put forward some methodological proposals to account for these migratory imaginaires and then show how some of the dominant representations of these tirailleurs are being reactivated by the younger generation in discourses on migration.

\section{The gradual establishment of the figure of the tirailleur}

\section{A brief Franco-Senegalese view of representations of the tirailleur, from World War One to the 2000s}

It is not easy to briefly outline the history of the military and social body of the tirailleurs, which, strictly speaking, lasted from 1857 to $1962 .{ }^{8}$ On the eve of World War One, the French authorities decided to recruit huge numbers of African soldiers to counter the demographic weight of Germany. ${ }^{9}$ While there were 6,000 African soldiers in 1900, almost 200,000 recruits from 'Black Africa' ultimately fought in the war on the French side (Michel 2003: 18, 191). The imaginaires engendered by these troops were diverse. The paternalistic representations of military officials were soon succeeded by a more complex language. In May 1917, in the French parliament, after the terrible episode of the Chemin des Dames, ${ }^{10}$

\footnotetext{
${ }^{6}$ The last stage of this recognition, on the part of a French politician, was the handover of the archives on the tragedy of Thiaroye to the Senegalese state by François Hollande on 1 December 2014, seventy years after the event. His address is available online at $<\mathrm{http}: / / w w w . d a i l y m o t i o n$. com/video/x2bfbr2>, accessed 25 March 2015.

${ }^{7}$ While Benedict Anderson's formula is now common in the social sciences, Christine Chivallon remarks in a critical article that Anderson leaves this notion of the 'imaginary' and the materialities that it presupposes largely undefined (Chivallon 2007).

${ }^{8}$ The date of 1962 corresponds to the end of the Algerian war and the demobilization of the last African soldiers active in the French army.

${ }^{9}$ These recruitments were examined from a theoretical angle in the work of Lieutenant-Colonel Charles Mangin (2011 [1911]).

${ }^{10}$ The Chemin des Dames was the site of several battles during World War One and is still seen as a particularly significant episode in French collective memory.
} 
the Senegalese deputy Blaise Diagne ${ }^{11}$ asserted that the Senegalese had been sacrificed (ibid.: 95-109). For Diagne, mentioning the sacrifice of the tirailleurs together with their courage, bravery and loyalty served other purposes: he wished to obtain new rights for the African populations, leading to the possibility of acquiring citizenship. Although veterans gained some rights at the end of World War One, Diagne's plan was not ultimately realized until the end of World War Two, and then only in a limited way, with the Lamine Gueye Act. ${ }^{12}$ However, the part played by these tirailleurs on the battlefields of World War One profoundly altered the imaginaires of European public opinion, particularly in France and Germany, and the way they viewed Africa (Lüsebrink 1998). ${ }^{13}$ The making of these representations partly impacted on Africa itself. The return of tirailleurs to the continent and the emergence of a new social group, the former combatants, led to unprecedented changes in power structures within their original societies. Recruits, often of servile origin, became 'chiefs', or at least were able to challenge their former lower social status. On the symbolic level, the post-war years were characterized by the French government's establishment of real policies of memorialization, such as those linked to armistice ceremonies (Michel 1990). There were also two statues erected in Dakar and Bamako that paid tribute to the colonial troops. Thus, in French public opinion, and even in Africa itself, the years of the interwar period can be seen as involving the emergence of a colonial 'hero', a hero who did not call into question the colonial order.

In the 1920s and 1930s, recruitment in West Africa became widespread, and, to a large extent, conscription became more or less accepted by the population (Echenberg 1991: 43). This recruitment accelerated with World War Two: over the five years of the conflict, almost 200,000 West Africans were conscripted under the French flag (ibid.: 158). ${ }^{14}$ World War Two provides an ideal environment for the study of tirailleurs by giving us a new understanding of the way in which the military functioned (Fargettas 2012) and by introducing interesting reflections on how a colonial situation was imported onto metropolitan soil, through the study of 'indigenous' prisoners of war (Mabon 2010). Gregory Mann points out that, in the 1940s, soldiers were most often recruited not from their own circles, as were former slaves at the outbreak of World War One, but in geographical areas with

\footnotetext{
${ }^{11}$ From the end of the nineteenth century, Senegalese nationals from the four cities - Dakar, Gorée, Rufisque and Saint-Louis - had French citizenship and participated in elections. Blaise Diagne was the first black African deputy to sit in the French parliament. For a portrait of Diagne, see Dieng (1990).

${ }^{12}$ The Lamine Gueye Act, which was passed in 1946, granted citizen status to all nationals of the overseas territories, even though the electoral body remained divided into two colleges (see Cooper 2014).

${ }^{13}$ In the aftermath of the war, and following the Treaty of Versailles, France occupied part of the Saar and the Rhineland. A violent campaign was launched in the German press against the presence of these troops, who were accused of perpetrating various abuses against the local population, particularly rape. This campaign was known as the 'black shame' and in turn generated a campaign in the French press that vigorously rejected these accusations, referring instead to a 'white shame': that is, the alleged lack of virtue among German women (Le Naour 2003).

${ }^{14}$ It is not easy to summarize the different careers of African tirailleurs during World War Two. It is worth noting that they fought against different enemies, both in metropolitan France, in North Africa, in sub-Saharan Africa and in the Levant. On the tirailleurs in this sequence of events, see Fargettas (2012).
} 
large labour-related migrations; conscripts were more often 'foreign' rather than of local origin (Mann 2006: 150). From 1946 and the beginning of the Indochina war, there was also a period of encounters between Indochinese women and Senegalese tirailleurs, although, back in Africa, these wives experienced a whole set of difficulties related to their arrival in the host societies (Zimmerman 2011: 119). These soldiers' experience of migration clearly involved more than a military ordeal. ${ }^{15}$

The end of the Algerian war in $1962^{16}$ and their final return to West Africa marked the end of the tirailleurs as a group. Nevertheless, in parallel with the struggles for independence, these soldiers, who were now veterans, left a lasting imprint on West African societies, and in particular on Senegalese society. ${ }^{17}$ In the late 1940s and early 1950s, the struggle for the rights of tirailleurs extended to other strata of society. The Senegalese Left - notably in the large and important federal party, the African Democratic Rally (RDA) - used this story to demand equivalent rights for both African and French soldiers and also for both French and African workers; the slogan 'equal work for equal pay' joined the struggle for equality of pensions among veterans and 'equal rights for an equal sacrifice'. Yet, at the end of the 1950s, the commitment of African soldiers to the imperial power and the repressive force they embodied against the aspirations of the Malagasy, Indochinese and Algerian peoples came into conflict with the internationalist militants of the Senegalese Left. Little by little, a new image was assigned to the tirailleur: that of the 'traitor'. ${ }^{18}$ In the context of national construction under the presidency of Senghor during the 1960s and 1970s, this image remained quite common in Senegalese social space, although it manifested itself in many ways. This negative image was constructed as a counterpart to another figure: that of Lat-Dior, a warrior and king of Kayor who died in 1886 and was considered in Senegal the 'last great opponent of colonization' (Mourre 2015). In 1981, Abdou Diouf became president of Senegal and one of the 'political cards' he played vis-à-vis the country's Senghorian heritage was to promote certain historical figures. The image of the tirailleurs was apparently reversed. The film Camp de Thiaroye (2003 [1988]), released in 1988, directed by Ousmane Sembène and Thierno Faty Sow and largely funded by the Abdou Diouf regime, testified to this transformation of the imaginaire. ${ }^{19}$ By emphasizing the repression of 1 December 1944, the directors wished to denounce the injustice suffered by these tirailleurs, just as they emphasized the role of these men in defence of metropolitan France in World War Two. ${ }^{20}$ Moreover, in the 1990s,

\footnotetext{
${ }^{15}$ The role of these troops in various imperial spaces, such as Madagascar, has also been emphasized (Ba 2012).

${ }^{16}$ Although the countries providing tirailleurs had gained their independence two years earlier, many of these men (except those from Guinea) remained mobilized in the French army.

${ }^{17}$ Unfortunately, to my knowledge, there is no comparative study of the role of these men in the processes leading to independence in the various colonial territories.

${ }^{18}$ This is the idea developed by Abdoulaye Ly, one of the leaders of the Senegalese Left, in his aptly titled work Mercenaires noirs (1957).

${ }^{19}$ Sembène had already made a film in 1971 implicating the tirailleurs: it was called Emitäi (2003 [1971]) and emphasized women's resistance. In this film, the tirailleurs were presented as a force of oppression in the service of the colonial power.

${ }^{20}$ For an analysis of the film, see Murphy (2000); for an analysis of the character of the tirailleur in Sembène's work, see Niang (2009).
} 
tirailleurs were also the subject of renewed attention by the scholarly community, as evidenced by several publications, by historians (Echenberg 1991; Lawler 1996 [1991]), sociologists (Fall 1987) ${ }^{21}$ and specialists in literature (Riesz and Schultz 1989).

However, it was really from the following decade onwards that the tirailleur returned to the Senegalese public and political scene.

\section{The combatants' past under Abdoulaye Wade}

In August 2004, the sixtieth anniversary of the landing in Provence in which African troops in the French army played an important role, the Senegalese state instituted a day of commemoration entitled 'Journée du tirailleur'. So here we need to analyse the memory of tirailleurs from the point of view of the use of this memory by the authorities. The analysis of memorializing policies is linked in this context to 'all the interventions of an authority covering the field of production, conservation and transmission of memories' (Michel 2010: 4). A dominant discourse, which assumed the values associated with the history of the Senegalese tirailleurs and made sense in contemporary Senegal, is now being heard more clearly. During the twelve years of President Wade's two mandates, the commemorations took place randomly (the Journée du tirailleur was abandoned when Macky Sall came to power in 2012). ${ }^{22}$ The Journée was held in 2004, 2005, 2006, 2008, 2009 and 2011. If the first Journée du tirailleur was pan-African, as shown by the dozen heads of state from the continent who attended and the initial desire to organize a commemoration that would rotate between countries, later events perhaps revealed an attempt to nationalize this past on the part of the state. The declarations of several political leaders, statements by military officials or, more widely, comments made in the press enable us to understand the importance of the socio-political use of certain values, such as courage, self-denial or the quest for identity - values that were directly associated with the tirailleurs. Through the use of a vocabulary that emphasized their heroic gesture - mainly in the two World Wars - the perception of the role of the tirailleurs changed; indeed, even the nature of the 'memorial regime' (Michel 2010)23 that connected these relationships to the past, the present and the future seemed to be changing. ${ }^{24}$

In 2004, what was most striking initially was the proactive aspect of this use of the past. Many events were organized to establish a history that would have a general impact. These public demonstrations took the form of speeches, the

\footnotetext{
${ }^{21}$ In this sense, the title of Mar Fall's book is particularly illustrative: Les africains noirs en France. Des tirailleurs sénégalais aux Blacks (Black Africans in France. From Senegalese tirailleurs to the 'Blacks') (1987).

${ }^{22}$ This does not mean that the new president has totally neglected this history; references to veterans are still found in the head of state's speeches to the nation.

${ }^{23}$ Johannes Michel's argument stems from a reading of both Reinhart Koselleck (2011 [1997]) and François Hartog (2012 [2003]). For Michel, 'a memorial regime is akin to a cognitive framework: that is, to a matrix of perceptions and representations of official public memories at a given time' (Michel 2010: 16).

${ }^{24} \mathrm{An}$ example of such a modification of these imaginaires was expressed in the very controversial inauguration of the 'Monument of the Renaissance' (De Jong and Foucher 2011; Dramé 2011; Mourre 2017b).
} 
(re)inauguration of a monument, ceremonies and legislative provisions. ${ }^{25}$ In a seemingly paradoxical manner, the vast majority of the narratives seeking to reconstruct the history of the African soldiers of the French Empire ignored the question of historicity. Rather than chronological sequences, it was above all moral notions that were transmitted by these new narratives, primarily those related to 'honour' (Iliffe 2005). One of the features of these commemorations was that they presented the tirailleurs as 'the forgotten men of history', thereby justifying the need for teaching and transmitting their story to the younger generation. In a speech he made in 2006, mainly addressed to serving Senegalese soldiers, the then Prime Minister Macky Sall, now president, said: 'They will not weary of being inspired by your sense of honour and your spirit of sacrifice. Their motto (they can kill us but we will not dishonour ourselves) springs from the example you have given to the younger generations. ${ }^{26}$ For the Senegalese authorities, it was probably a question of trying to draw up an agreed genealogy of the values of the colonial and postcolonial army. On this occasion the press emphasized the continuities between the tirailleurs and the modern army. One of the tasks that President Wade seemed to have given himself was that of passing this information on to schoolchildren. In 2008, he announced that the history of tirailleurs would now be taught in schools: a textbook on the life of tirailleurs was to be used in elementary school classes in the following school year, helping to combat the injustice of the "lack of interest with which the history of the tirailleurs is treated' ${ }^{27}$ The presidential communiqué stated that this 'history' should concern all age groups: 'From now on, the libraries will be provided with textbooks on the career of the tirailleurs and, from the beginning of the school year, the history of our valiant fighters will be included in the curricula from first year at secondary school to university level. ${ }^{28}$ These statements may not have produced any effects, ${ }^{29}$ but they do show how the Senegalese state tried to stipulate a history that would make sense. While Abdoulaye Wade played a catalytic role in shaping the colonial past, many other intermediary factors explain how this memory was shaped.

Thus, the military now organizes what it considers to be 'its' history. This is especially the task of the Armed Forces Museum. The idea of an army museum emerged in the 1980s (Ginio 2006: 146). For museum officials, the aim was less to write a history of the corps of tirailleurs, or a narrative of the modern Senegalese army, than to trace the odyssey of the combatants over the longue

\footnotetext{
${ }^{25}$ The statue is that of 'Demba and Dupont', representing an African soldier and a French one. This statue was unveiled in 1923 in Dakar, before being dismantled in 1983 under the presidency of Abdou Diouf as a symbol of colonial paternalism. Two legislative provisions were made: one to make 23 August, the date of the Journée du tirailleur, a public holiday, and the other being the declaration of the cemetery of Thiaroye as a national cemetery.

${ }^{26}$ Abdoulaye Thiam, 'Journée du tirailleur. Moment intense de communion', Le Soleil, 24 August 2006.

${ }^{27}$ ' $L$ 'histoire des tirailleurs sera enseignée à la prochaine rentrée scolaire, annonce Abdoulaye Wade', APS, 19 July 2008.

${ }^{28}$ Maguette Guèye, 'Annonce du président Wade. L'histoire des tirailleurs enseignée à la rentrée', Le Soleil, 18 September 2008.

${ }^{29}$ The Senegalese state has proposed a 'General history of Senegal' based on the model of UNESCO's General History of Africa. The first volume should come out around the end of 2018.
} 
durée. ${ }^{30}$ In an interview, the museum's scientific adviser, the historian Mamadou Koné, testified:

Our ambition is to write our military history. The memory of combat did not begin with colonization. In the precolonial period, there were well-structured traditional armies that resisted colonial penetration. Our ambition is to begin history from this period, and come up to the present time with the modern armed forces. ${ }^{31}$

In Koné's words, the adventure of the $c e d d o^{32}$ is directly related to that of the tirailleurs and plays a part in the writing of the modern jaambaar. Significantly, it should be noted that, in Wolof, the term jaambaar denotes a soldier but also means being courageous. ${ }^{33}$

For some ten years, and on different levels, the Senegalese government has tried to narrate the history of a social group, a history intimately tied to the colonial period, while at the same time linking it to contemporary issues. Before turning to the reinterpretation of this dominant narrative, we must take into consideration one of the most important social dynamics in Senegal in the 2000s: the phenomenon of migration, seen less from an economic perspective than through the representations it has generated.

\section{Different migratory imaginaires in Senegal}

\section{The tirailleur as a migrant in the society he leaves and the society he joins}

While Gregory Mann points out that tirailleurs may be first and foremost migrants who have generated a specific military culture in West Africa (Mann 2006: 147), ${ }^{34}$ few studies take any interest in this aspect of the history of the tirailleurs, except perhaps Myron Echenberg. For Echenberg, recruitment processes and the displacement of these populations make it possible to understand something of the social transformations and class formation in colonial times in French West Africa (Echenberg 1980: 432). For Echenberg, the soldiers were to be seen as uniformed workers (Echenberg 1978). ${ }^{35}$ This Marxist paradigm, however interesting as it might be, does not integrate the dynamics of these migrations into the imaginaire. Focusing on the case of the conurbation of Dakar at the beginning of the twentieth century supplies a few lines of inquiry that may help us answer this problem of linking migration and the imaginaire.

\footnotetext{
${ }^{30}$ This phenomenon has been observed in different countries, especially at the time of independence. For an overview of various national situations, see Chrétien and Triaud (1999).

${ }^{31}$ Interview with Mamadou Koné, Dakar, March 2011.

${ }^{32}$ The ceddos were the warriors of the Senegambian region during the 'precolonial' period.

${ }^{33}$ Diouf's French-Wolof dictionary gives this definition for the word jaambaar: 'Brave, courageous, heroic person. Wax-dëgg jaambaar la: frankly, he’s a brave man’ (Diouf 2003).

${ }^{34}$ For Gregory Mann, the military culture formed by the corps of tirailleurs - a culture that is never unified and homogeneous but depends on different places and political eras - is above all a culture of movement.

${ }^{35}$ Indeed, recruitment principles imposed a second stage when the soldiers were subjected to forced labour. On this question, see Babacar Fall (1993: 157-99).
} 
In 1902, Dakar became the capital of French West Africa. In the city, and especially in the garrisons, the massive presence of soldiers soon led to different types of social relations. We can understand these daily interactions by looking at the example of the camp of Thiaroye. The specificity of this space lies in the link between the forced migratory experience of the tirailleurs of West Africamainly from French Sudan and Upper Volta, Bambara and Mossi - and the exponential urbanization of the Dakar conurbation in the twentieth century. In 1905, the Lebou people who occupied the Thiaroye area signed a treaty conceding their land to the French colonial authorities for the installation of military barracks. ${ }^{36}$ In 1913, as World War One was brewing in Europe, these authorities decided to extend the military camp. The mass conscriptions that occurred between 1914 and 1918 corresponded to an emigration from the countryside to the cities - not only in Senegal but also on a larger regional scale - with recruits then settling into a new space. In the early 1920 s, the camp of Thiaroye became one of the largest in French West Africa ${ }^{37}-$ perhaps even the largest. This camp was both a training camp, where tirailleurs remained for a few weeks or sometimes up to several months, and a place of transit for those departing to or returning from military fronts. These factors suggest that we need to think about internal migration within the African continent, whether or not it was constrained by the colonial power. ${ }^{38}$ The soldiers recruited for the French army were thus the first 'mass migrants' to go to metropolitan France.

In the wake of World War One, in line with the 'doctrine' of colonial development, few Africans went to metropolitan France and even fewer stayed there, except perhaps sailors (Bertoncello and Bredeloup 1999; Manchuelle 1997) and a few students - many of whom became political activists (Dewitte 1985). Migrations from West Africa to France remained relatively small-scale before World War One. Beginning in 1920, some of the demobilized tirailleurs wanted to remain in France; there was 'a significant number ... in the major French ports, either sailors or dockers. Some of these seamen [would] establish a connection between France and its colonies' (ibid.: 10). In 1926, in France, there was a 'total of 2,580 African and Malagasy nationals, 1,685 of whom were from French West Africa' (ibid.: 25), even though these figures do not take account of the originaires of the four cities - Dakar, Saint-Louis, Gorée, Rufisque - with French citizenship, and they ignore Africans there illegally, as, by definition, these lay beyond the scope of the census. ${ }^{39}$ But if the history of the African presence in France before World War Two is often gauged in terms of the major intellectuals involved, such as Léopold Sédar Senghor (also an ex-tirailleur), or in terms of artists or sportsmen (Blanchard 2012), it is more rarely discussed in terms of collective imaginaires.

\footnotetext{
${ }^{36}$ On the link between space, the space of migrations and memory, see Casentini (this issue).

${ }^{37}$ At the time of World War One, there were several other camps in Senegal - Rufisque, Thiès and Ouakam - which succeeded the oldest ones, Dakar and St Louis. In French West Africa, there were also the camps of Bingerville in Côte d'Ivoire and Kati in Mali.

${ }^{38}$ See Declich and Nair (this issue) for the cases of Tanzania and Uganda respectively.

${ }^{39} \mathrm{~A}$ range of between 3,000 and 5,000 thus seems more probable (Dewitte 1985: 26).
} 
The arrival of West African nationals in significant numbers began in the late 1950s, just as Senegalese tirailleurs disappeared as a social body. ${ }^{40}$ After 1974 and the oil shock, the tightening of immigration controls in France meant the end of widespread migration; at the same time, processes of family reunification were instituted. Immigrants were not only young men but also included women and children. These demographic changes led to paradigm shifts in the construction of the 'migrant object', while transforming these migratory figures by making them more complex.

\section{The construction of the figure of the migrant since independence: from worker to adventurer}

From the early 1960s until the early 1980s, West African migrations, particularly from the region of the Senegal River, were analysed mainly from the perspective of a Marxist paradigm. The migrant - who was essentially seen as an immigrant was often considered illiterate, someone coming from a rural area who was exploited for his labour power (Kuczynski and Razy 2009: 82). In the 1990s, following research in other areas, notably Alain Tarrius's (1992) work on Marseille and the Maghreb, studies of migration tended to focus less on immigration and the place of immigrants in the host society - questions formulated in French public debate under the term 'integration' - and more on phenomena of circulation (Tarrius 1992). The immigrant also seemed to be changing into an entrepreneur. In the case of sub-Saharan African nationals, some studies underlined these dynamics in connection with the Congolese diaspora in Paris. The studies by Didier Gandoulou (1989) on the phenomenon of 'clothing' or 'gear' (la sape) have shown that the migration experience was not necessarily linked to economic distress but 'conceived as an initiatory journey; it allowed them [migrants] to turn designer clothes into material and symbolic capital' (Kuczynski and Razy 2009: 94). Nevertheless, it should be noted that, in the Senegalese case, networks of Sufi orders were at the centre of any analysis. Studies no longer focused on the face-to-face relationship between the host society and the home society, but partly reintroduced the subjectivity of the migrant, understood within transnational networks (Bava 2003).

From the perspective of the home society, these different tempos of migration have generated different representations, which then produce different figures conceived in collective terms. Mahamet Timera shows that, in Senegal in the 1960s, through the various cultural productions of a certain elite - books, songs and films - the migratory project was not perceived as an achievement on the part of the migrant. Dominant representations in the public arena drew on 'the registers of suspicion, guilt, stigmatization, victimization and poverty' (Timera 2014: 30). ${ }^{41}$ These dominant representations were then linked to a 'golden age' of

\footnotetext{
${ }^{40}$ While we have seen that veterans occupy an important place in the national imaginaire, the demobilization of African soldiers must also be analysed from the point of view of the constitution of national armies.

${ }^{41}$ Timera emphasizes that two narratives coexisted until the 1970s:

the minority and subordinate narrative deployed in the 'moral space' specific to the communities engaged in emigration and that of the majority groups of the state which devalue these 'deserters' and these 'street sweepers' of the streets of Paris ... For the groups concerned by
} 
nationalism in which emigration was "thought of as "voting with your feet", a way of challenging the nation and its elites' (ibid.). The various narratives that recount this social experience highlight the issue of being uprooted. The experience of travelling and living abroad is understood as a separation, but also as a confrontation between a rural universe, that of the African village, and an urban Western world. But as these phenomena of emigration and the reception of migrants in France gradually changed, the Senegalese seemed to discover, on a wider scale, the migratory experience of their fellow citizens. By analysing these dynamics in terms of imaginaires, and taking up Castoriadis's propositions, we see that it is 'impossible to maintain an intrinsic distinction between the social and the historical, even if it is a matter of affirming that historicity is the "essential attribute" of society or that society is the "essential presupposition" of history" (Castoriadis 1987: 215). To propose this does not imply that we cannot identify certain turning points in the institution of these imagined categories. In 1983, a delegated ministry was set up to take charge of the Senegalese diaspora. Thus, in the 1980s:

there would emerge in Senegalese society new figures of the emigrant that stood out against the figure of the stigmatized worker. These new figures promoted by the state and popularized by the media were those of artistic elites - almost all musicians - of footballers and intellectual, scientific and technical personalities, in short of prestigious and remarkable individuals. (Timera 2014: 36)

In this sense, this figure of the migrant is clearly shaped and instituted by collective representations formed within the Senegalese nation. They are created in a relationship of desire, and sometimes of apprehension, constituting the journey and the discovery of a certain otherness (Fouquet 2008). It is mainly this model that is considered in current analyses of migratory representations in Senegal (Diop 2008). Nevertheless, these glorious figures do not conceal completely the image of the migrant as a victim of the cruelties of the economic system. These multiple constructions of the figure of the migrant are thus ambiguous, and they reflect a model of success where one of the dominant traits is that of resourcefulness, which in turn was one of the important factors in the identity-forming processes of Senegalese youth in the early 2000s (Havard 2001).

It is now necessary to identify the ways in which these representations echo the memorializing policies of the state concerning veterans.

\section{Blood debt and the grandsons of tirailleurs}

\section{Investigating migratory imaginaires: for an epistemological pluralism}

The historical memory of Senegalese tirailleurs formalized by the state may refer to a living memory borne by individuals, but it must be understood in dialogue with a memory inscribed in a more distant time, especially when the latter

the phenomenon, migrants receive the honours of the griots and of society as a whole. The act of leaving may be forced on them, but it is strongly integrated into the strategies and expectations of the group. (Timera 2014: 34-5) 
incorporates aspects of the 'Black Atlantic' (Gilroy 1993). ${ }^{42}$ These processes of writing the past have an impact on the subjectivities of the actors, whether they are the young people who remain in the country or those who set out on 'the migratory adventure' (Bredeloup 2008). We have already seen the possible combinations of two historiographies: one that takes as its object the Senegalese tirailleurs and one that focuses on the migratory phenomenon. Furthermore, what led to this connection was the importance of these two phenomena in the 2000s: the return to the public stage of 'the' tirailleur and the mass exodus of thousands of young people in unprecedented (and often dramatic) circumstances. We need to highlight the dominant discourse on migration and this collective memory that takes as its object the tirailleurs. It is ultimately the link between memory and imaginaire that needs to be clarified.

Maurice Halbwachs describes the notion of collective memory as the effective sharing of a representation by a group, the reconstruction of memories more than their creation (Halbwachs 1980). As a sociologist of the 1930s, in the Durkheimian tradition, Halbwachs focused mainly on the national level. If these propositions seem valid - especially when they are expressed through the notion of 'social frameworks of memory' (Halbwachs 1992), allowing us to articulate an interrelation between the individual memory and the group memory - we can probably extend his research project to a wider postcolonial area. The analyses of Marie Rodet and Christophe Reinprecht describe environments of memory rather than 'realms of memory' or lieux de mémoire (Nora 1996) (the tirailleurs are such 'realms' or places for the Senegalese nation) and invite us to think about the effectiveness of these representations for subordinate actors in a migratory context. Thus, they note, "mobilities are real performed "memoryscapes" of social and political relations, both in the home milieu and in the country of arrival' (Rodet and Reinprecht 2013: 10). Describing the bodies of individuals as bearers of memory (ibid.) links them to certain social practices that may be explained by the revelation of a Senegalese, or even a West African, ethos. Joe Lunn recalled that the Senegalese tirailleurs of World War One set up a whole series of protective rituals to avoid death and the dangers of war but also to face various episodes of this 'adventure', such as, for example, the sea crossing (Lunn 1999: 100). Some of these elements would be addressed in the 2000s by migrants attempting to reach Europe by sea. The film by Senegalese director Moussa Touré, The Pirogue, released in 2012, selected in Cannes and a bronze medal winner at FESPACO (the Pan-African Film and Television Festival of Ouagadougou) in 2013, shows how these rituals are at the heart of the destinies of migrants trying to reach Europe. When we analyse the imaginaires linked to migratory practices, we must also integrate other sources, such as cultural works. Thus, although the historiographic corpus on tirailleurs does not usually include migratory questions, novelists have been largely inspired by this theme, highlighting recruits' encounters with the 'white world' and the often painful experience of returning to their original societies (Diop 1989).

Several studies from the early 2000s show the need to think about migration and the resulting changes in subjectivities among African youths. These logics of

\footnotetext{
${ }^{42}$ Slavery thus comes up regularly during discussions with young Senegalese people, presumably because the future of many of their generation in Senegal is a 'dead end'.
} 
extraversion reflect the modes of differentiation and the way in which the person who left home is viewed by contrasting him with those who remained; they thus reveal certain conflictual relations (Fouquet 2008: 247). The quest for departure becomes a means of growing socially in a society riddled with job insecurity; the immigration project in Senegal is part of an economic plan as well as a quest for identity. This adventure, which allows the migrant to become a warrior, presupposes a great deal of temerity and even pride, and seems connected to 'a warlike perception' (Bredeloup 2008: 296-7). These perspectives are reminiscent of the trajectories of the tirailleurs, who voluntarily joined the French army, especially after World War Two (Echenberg 1991). An understanding of these processes, which may seem comparable, must be integrated within a certain postcolonial temporality. Following the work of Arjun Appadurai, the institutionalization of these representations deserves attention in its own right and also because they stimulate the imagination. Appadurai defines this imagination as 'neither purely emancipatory nor entirely disciplined', 'a space of contestation in which individuals and groups seek to annex the global world into their own practices of the modern' (Appadurai 1996: 4). How then can we account for the diversity of the imaginaires produced?

Several structures can be established. When dealing with the question of informal immigration among young people in the Dakar suburbs, a comparison is drawn between the figure of the migrant adventurer and that of the combatant. The younger generation, often forced to face precarious living conditions, re-appropriates this historical memory in order to interpret contemporary phenomena. Excerpts from songs, interviews with young Senegalese men (especially from the hip-hop movement) and participant observation among high-school students (showing the film Camp de Thiaroye on two occasions and organizing discussion sessions afterwards) have thus made it possible to highlight the recycling of certain representations.

\section{The imaginaire as a reinterpretation of historical memory?}

By examining the various stages of this process of collective remembrance, the ethnographic approach helps us understand the ways in which representations of tirailleurs constitute a factor in the processes of subjectivation of the younger generation (Mourre 2012). It should be noted that this approach - working with teenagers - is a response to a demographic reality: the latest figures available indicated that more than 50 per cent of the Senegalese population was under the age of twenty, even if only 24 per cent of the age group of those aged ten to nineteen were enrolled in school. ${ }^{43}$ The number of adolescents in the two sample groups at the two sessions made it possible to evaluate the contents of a collective or even a national memory, at least for this age group and for the young people attending school. Studying memory through such an ethnographic approach showing the film in classrooms, putting various documents relating to the story of the tirailleurs on the walls, ${ }^{44}$ and subsequently organizing conversations in

\footnotetext{
${ }^{43}$ See the National Agency for Statistics and Demography of Senegal and the UNICEF figures at <http://www.ansd.sn> and <http://www.unicef.org>, both accessed 25 March 2015.

${ }^{44}$ Among these documents were extracts from the archives relating to the killings of 1 December 1944, cultural works, especially poems, related to this event, and photographs of veterans.
} 
focus groups - makes it possible to place the researcher at the centre of the interactions that determine the acquisition and formation of new representations and new imaginaires. By combining notions such as honour and courage (in the tirailleurs) as opposed to betrayal and cowardice (in the French government), these representations are also those fostered by the Senegalese state. Some students emphasized the notion of betrayal in their understanding of the events of 1 December 1944: 'Until now, the tirailleurs have not had the recognition they should have; France must have a bare minimum of recognition because there are many things it should have done for them and has not done, and France must respect the tirailleurs. ${ }^{45}$ But other values were also mentioned; these concerned the positive memory attached to the fighters:

I truly want to emphasize their bravery, because they really were brave, they struggled, they showed bravery. When I followed the film I was amazed, because really, seeing people fighting for something, I was proud of them, their bravery really made an impression on me. ${ }^{46}$

This imaginaire that can be heard in the classroom is also expressed and formalized by other elements of the younger generation. A study of the Senegalese rap movement, which uses this vocabulary in line with its own preoccupations, suggests a few lines of inquiry.

As young cultures, hip hop and Senegalese rap are modes of resistance, phenomena that are widely found in other contexts. Focusing on the grammar of this genre allows us to question the memorial practices of power and the interpretations they generate (Niang 2013). Because they are associated with notions of courage, bravery and dignity, ${ }^{47}$ which are often linked in the discourse of those concerned with an 'African authenticity', these combatants personify a figure of moral force, which becomes one of the topoi of Senegalese youth. Rehabilitating a past that is considered unjustly forgotten by comparing it to a present judged to be iniquitous plays a part in this struggle. The words in rappers' songs thus regularly draw on the blood debt contracted by the French state vis-à-vis the tirailleurs. In the track 'J'accuse', rapper Didier Awadi, surely the most famous Senegalese rapper, says:

You forget a little too quickly all the Senegalese tirailleurs, by force enlisted, deported, now expelled, they came, they fought, and they conquered, your country was destroyed and they came back and they rebuilt it ... I say that France is very ungrateful when it talks about visas, when our fathers left to fight for it there were no visas, no there were no visas. (Awadi 2007)

Here, the ingratitude of France is explicitly connected with the migration question. Interviews with several members of rap groups in the Dakar suburbs ${ }^{48}$ confirm

\footnotetext{
${ }^{45}$ Interview with Ousmane, Pikine, July 2012.

${ }^{46}$ Interview with Anta, Pikine, July 2012.

${ }^{47} \mathrm{On}$ the question of dignity in the West African region, see Rodet and County (this issue), who propose this notion with reference to an extremely limited historical temporality, the collapse of the Mali Federation in August 1960.

${ }^{48}$ While Senegalese rap historically appeared among the youth of Dakar's middle class, the interviews carried out here were with young people from the suburbs who were more severely affected by the socio-economic crisis.
} 
this perception. France's treachery no longer concerns only the tirailleurs, but perhaps more generally the continent as a whole. Sister LB, one of the few women in the Senegalese rap movement, a member of the rap group Fippu Clan and a resident of Thiaroye-sur-Mer, says:

I like Awadi's album ${ }^{49}$ because it reminds us of true historians, true ancestors, not those in books at school. Awadi took their characters, Martin Luther King is a warrior, he fought until the last abode [death]. He showed that Africa could do otherwise. Why Obama? ... Because Lumumba had shown it, Sankara had shown it, Martin Luther King had shown it, but we didn't know ... Obama understood the message, and showed that it's time for Africa and Africans to raise the flag. ${ }^{50}$

While rappers refer to certain figures in the history of the continent or the diaspora, they place their cultural productions within the social space of the suburbs - a physical space that has a profound metaphorical dimension. Iba, from the collective Carapin Thiaroye 44, suggests that the memory of the African fighters is inscribed in the homeland: "At the moment, we are shooting a video, the sound is called "patriot", "being patriotic". We have sequences that need to be shot there, in the cemetery [of Thiaroye].' ${ }^{51}$ For Iba, the history of the Senegalese tirailleurs and this fighting ethos can also be related directly to the problem of migration:

The young men who leave for Europe, how shall I put it? ... They are really warriors ... For me, they're the same as tirailleurs. The tirailleurs did everything for their nation; as for the people who take to pirogues, they too are doing all they can to look for something, perhaps wealth, to support their parents, their families. ${ }^{52}$

Collective memory seems to be linked here to the path followed by individuals considered as a group, while the imaginaire as a 'magma of significations' (Castoriadis 1987: 237) refers to an earlier, more anthropological period. It may thus be appropriate to add a third term to the two preceding ones: identity.

\section{Conclusion}

The modification of migratory imaginaires, based on the Senegalese case, can be understood essentially as a result of the rising power of desire, linked to an increasingly globalized and interconnected world; but it must also be reduced to a historical memory rooted in a home territory over a longer or shorter time. In the $2000 \mathrm{~s}$, to highlight the courage of the tirailleurs, one of the mottos associated with them was: 'These men can be killed but not dishonoured.' This phrase, probably apocryphal, is attributed to Governor General Faidherbe, who, at the end of the nineteenth century, is said to have uttered it when faced with the resistance of the ceddo warriors of Lat-Dior. As we have seen, it became the motto of the Senegalese army after independence - with slight modification. In a sense, this

\footnotetext{
${ }^{49}$ This references the album Président d'Afrique (Awadi 2010).

${ }^{50}$ Interview with Sister LB, Thiaroye, February 2011.

${ }^{51}$ Interview with Iba, Thiaroye, February 2011.

${ }^{52}$ Ibid.
} 
phrase echoes the formula 'Barça or Barzakh', with which young migrants say they prefer death to the social opprobrium of poverty and staying in their own country. By tracing a history of memory, concerned 'not with the past as such, but only with the past as it is remembered' (Assmann 1997: 9), we have been able to follow the establishment of two twentieth-century figures - the migrant and the veteran - that today occupy a central place in Senegalese society. The figures of the migrant and the veteran are real 'characters', revealing distinct social processes; however, it is the stages of their imagined construction that have been at the centre of the analysis here. Through the construction of a new postcolonial narrative of national unity, we can see the political will, especially on the part of the state, to produce an image of the Senegalese combatant rooted in the precolonial period and linked to a West African authenticity. This is less a question of conveying a factual history than of recounting a notional history, one in which the sacrifice and courage of African warriors can represent a discourse on everyday life, or at least echo it, as the majority of the Senegalese population lives in a precarious situation. For ten years in Senegal, this consensual narrative and its reception in the public sphere have undoubtedly been linked to the need for a positive story; veterans or 'tirailleurs' as a topic of discourse seem to have become omnipotent objects, 'a fetish' of postcoloniality, to use the terms of Mbembe (2001). It is such a construction that seems to be repeated in many discourses on migration.

The study of 'milieus of memory' (Rodet and Reinprecht 2013), in which memories are formed, and through them social interactions, allows us to investigate a memory of experience (that of the tirailleurs) and a memory in experience (the actualization of the patterns of perception of their story); this project lay at the heart of the sociology of memory developed by Maurice Halbwachs (Sabourin 1997). However, beyond these phenomena of remembrance, this article has tried to show that at the heart of these processes was a phantasmagorical dimension based on a work of the imaginaire (Castoriadis 1987). Such actualizations of the real thus manifest themselves on several scales, from the perspective of political discourse - both French and Senegalese - as well as on a more local level among the Senegalese younger generation. A multi-sited analysis of these narratives is therefore required in order to better understand the notions of courage or adventure that are current today in Senegalese society, thereby informing contemporary and emerging processes of identity formation.

\section{Supplementary material}

The original French version of this article is available online at $<$ https://doi.org/10. 1017/S0001972018000207>.

\section{References}

Anderson, B. (2016) Imagined Communities: reflections on the origin and spread of nationalism. London: Verso.

Appadurai, A. (1996) Modernity at Large: cultural dimensions of globalization. Minneapolis MN and London: University of Minnesota Press. 
Assmann, J. (1997) Moses the Egyptian: the memory of Egypt in Western monotheism. Cambridge MA and London: Harvard University Press.

Ba, A. (2012) Les 'Sénégalais' à Madagascar. Militaires ouest-africains dans la conquête et la colonisation de la Grande île (1895-1960). Paris: L'Harmattan.

Ba Konaré, A. (ed.) (2009) Petit précis de remise à niveau sur l'histoire africaine à l'usage du président Sarkozy. Paris: La Découverte.

Bava, S. (2003) 'De la "baraka aux affaires": ethos économico-religieux et transnationalité chez les migrants sénégalais mourides', Revue Européenne des Migrations Internationales 19 (2): 69-84.

Bertoncello, B. and S. Bredeloup (1999) 'Le Marseille des marins africains', Revue Européenne des Migrations Internationales 15 (3): 177-97.

Blanchard, P. (ed.) (2012) La France noire. Présences et migrations des Afriques, des Amériques et de l'océan Indien en France. Paris: La Découverte.

Blin, T. (2005) Les sans-papiers de Saint-Bernard. Paris: L'Harmattan.

Bouilly, E. (2008) 'Les enjeux féminins de la migration masculine: le collectif des femmes pour la lutte contre l'immigration clandestine de Thiaroye-sur-mer', Politique Africaine 109: 16-31.

Bredeloup, S. (2008) 'L'aventurier: une figure de la migration africaine', Cahiers Internationaux de Sociologie 125 (2): 281-306.

Castoriadis, C. (1987) The Imaginary Institution of Society. Translated by Kathleen Blamey. Cambridge: Polity.

Chivallon, C. (2007) 'Retour sur la "Communauté imagine" d'Anderson. Essai de clarification théorique d'une notion restée floue', Raisons Politiques 27 (3): 131-72.

Chrétien, J.-P. (ed.) (2008) L'Afrique de Sarkozy. Un déni d'histoire. Paris: Karthala.

Chrétien, J.-P. and J.-L. Triaud (eds) (1999) Histoire d'Afrique, les enjeux de mémoire. Paris: Karthala.

Cooper, F. (2014) Français et Africains? Être citoyen au temps de la décolonisation. Paris: Payot.

De Jong, F. and V. Foucher (2011) 'La tragédie du roi Abdoulaye. Néomodernisme et Renaissance africaine dans le Sénégal contemporain', Politique Africaine 118: 187-204.

Dewitte, P. (1985) Les mouvements nègres en France, 1919-1939. Paris: L'Harmattan.

Dieng, A. A. (1990) Blaise Diagne, premier député africain. Paris: Chaka.

Diop, M.-C. (ed.) (2008) Le Sénégal des migrations. Paris: Karthala.

Diop, P. S. (1989) 'La figure du Tirailleur sénégalais dans le roman sénégalais, 1920-1985' in J. Riesz and J. Schultz (eds), Tirailleurs sénégalais: présentations littéraires et figuratives de soldats africains au service de la France. Frankfurt and Paris: Lang.

Diouf, J.-L. (2003) Dictionnaire wolof-français et français-wolof. Paris: Karthala.

Dramé, P. (2011) 'La monumentalisation du passé colonial et esclavagiste au Sénégal: controverse et rejet de la renaissance africaine', Revue de la Société Historique du Canada 22 (2): 237-65.

Echenberg, M. (1978) 'The Senegalese soldiers' uprising of 1944' in R. Cohen, J. Copans and P. C. W. Gutkind (eds), African Labor History. Beverly Hills $\mathrm{CA}$ and London: Sage.

Echenberg, M. (1980) 'Les migrations militaires en Afrique occidentale française, 1900-1945', Revue Canadienne des Études Africaines 14 (3): 429-50. 
Echenberg, M. (1991) Colonial Conscripts: the tirailleurs sénégalais in French West Africa, 1857-1960. Portsmouth NH and London: Heinemann and J. Currey.

Fall, M. (1987) Les africains noirs en France. Des tirailleurs sénégalais aux Blacks. Paris: L'Harmattan.

Fall, B. (1993) Le travail forcé en Afrique occidentale française, 1900-1946. Paris: Karthala.

Fargettas, J. (2012) Les tirailleurs sénégalais. Les soldats noirs entre légendes et réalités: 1939-1945. Paris: Tallandier.

Fouquet, T. (2008) 'Migrations et "glocalisation” dakaroises' in M.-C. Diop (ed.), Le Sénégal des migrations. Paris: Karthala.

Gandoulou, D. (1989) Mxurs et aventures des Congolais à Paris. Paris: L'Harmattan.

Gilroy, P. (1993) The Black Atlantic: modernity and double consciousness. Cambridge MA: Harvard University Press.

Ginio, R. (2006) 'African colonial soldiers between memory and forgetfulness: the case of post-colonial Senegal', Outre-mers 93 (350): 141-55.

Halbwachs, M. (1980) The Collective Memory. Translated by F. J. Ditter Jr and V. Y. Ditter. New York NY and London: Harper and Row.

Halbwachs, M. (1992) On Collective Memory. Edited and translated by L. A. Coser. Chicago IL: Chicago University Press.

Hartog, F. (2012 [2003]) Régime d'historicité: présentisme et expériences du temps. Paris: Éditions du Seuil.

Havard, J.-F. (2001) 'Ethos "Bul Faale" et nouvelles figures de la réussite au Sénégal', Politique Africaine 82: 63-77.

Iliffe, J. (2005) Honour in African History. Cambridge: Cambridge University Press.

Kamian, B. (2001) Des tranchés de Verdun à l'église Saint-Bernard. 80,000 combattants maliens au secours de la France, 1914-1918 et 1939-1945. Paris: Karthala.

Koselleck, R. (2011 [1997]) L'expérience de l'histoire. Paris: Points.

Kuczynski, L. and E. Razy (2009) 'Anthropologie et migrations africaines en France: une généalogie des recherches', Revue Européenne des Migrations Internationales 25 (3): 79-100.

Lawler, N. (1996 [1991]) Soldats d'infortune. Les tirailleurs ivoiriens de la Deuxième guerre mondiale. Paris: L'Harmattan.

Le Naour, J.-Y. (2003) La honte noire. L'Allemagne et les troupes coloniales françaises, 1914-1945. Paris: Hachette.

Lunn, J. (1999) Memoirs of the Maelstrom: a Senegalese oral history of the First World War. Portsmouth NH: Heinemann.

Lüsebrink, H.-J. (1998) 'Les Tirailleurs sénégalais et l'anthropologie coloniale. Un litige franco-allemand aux lendemains de la Première Guerre mondiale', Éthiophiques $50-1$.

Ly, A. (1957) Mercenaires noirs. Notes sur une forme d'exploitation des Africains. Paris: Présence Africaine.

Mabon, A. (2010) Prisonniers de guerre 'indigènes'. Visages oubliés de la France occupée. Paris: La Découverte.

Manchuelle, F. (1997) Willing Migrants: Soninke labor diasporas, 1848-1960. Athens $\mathrm{OH}$ and London: Ohio University Press and James Currey.

Mangin, C. (2011 [1911]) La force noire. Paris: L'Harmattan. 
Mann, G. (2006) Native Sons: West African veterans and France in the twentieth century. Durham NC and London: Duke University Press.

Mbembe, A. (2001) On the Postcolony. Berkeley CA: University of California Press.

Michel, J. (2010) Gouverner les mémoires. Les politiques mémorielles en France. Paris: Presses Universitaires de France.

Michel, M. (1990) “"Mémoire officielle", discours et pratique coloniale. Le 14 juillet et le 11 novembre au Sénégal entre les deux guerres', Revue Française d'Histoire d'Outre-mer 77 (287): 145-58.

Michel, M. (2003) Les Africains et la Grande Guerre. L'Appel à l'Afrique (19141918). Paris: Karthala.

Mourre, M. (2012) 'L'ethnographie d'une mémoire sociale. À propos d'un film sur 1'histoire coloniale au Sénégal', New Cultural Frontiers 3: 119-34.

Mourre, M. (2015) 'Mobiliser le passé au temps de l'indépendance. Le cas du Sénégal, 1958-1980', Matériaux pour l'Histoire de Notre Temps: Mémoires et Constructions Nationales en Afrique 117-18: 24-30.

Mourre, M. (2017a) Thiaroye 1944. Histoire et mémoire d'un massacre colonial. Rennes: Presses Universitaires de Rennes.

Mourre, M. (2017b) 'La Renaissance africaine: des idées à la pierre. L'infrastructure de Cheikh Anta Diop, la culture de Léopold Sédar Senghor, la sculpture d'Abdoulaye Wade', Cahiers d'Études Africaines 227: 719-49.

Murphy, D. (2000) Sembene: imagining alternatives in film and fiction. Oxford: James Currey.

Niang, A. (2013) 'Le mouvement hip hop au Sénégal. Des marges à une légitimité sociale montante' in M.-C. Diop (ed.), Le Sénégal sous Abdoulaye Wade. Le Sopi à l'épreuve du pouvoir. Paris: Karthala.

Niang, S. (2009) 'Les tirailleurs sénégalais sur les écrans africains: les films de Sembene Ousmane' in R. Little (ed.), Lucie Cousturier, les tirailleurs sénégalais et la question coloniale. Paris: L'Harmattan.

Nora, P. (1996) 'Between memory and history' in Realms of Memory: rethinking the French past. Vol. 1. Translated by A. Goldhammer. New York NY: Columbia University Press.

Riesz, J. and J. Schultz (eds) (1989) Tirailleurs sénégalais: présentations littéraires et figuratives de soldats africains au service de la France. Frankfurt and Paris: Lang.

Rodet, M. and C. Reinprecht (2013) 'Éditorial. Mémoire et migrations en Afrique de l'Ouest', Revue Européenne des Migrations Internationales 29 (1): 7-22.

Sabourin, P. (1997) 'Perspective sur la mémoire sociale de Maurice Halbwachs', Sociologie et Société XXIV (2): 139-61.

Tarrius, A. (1992) Les fourmis d'Europe: migrants riches, migrants pauvres et nouvelles villes internationales. Paris: L'Harmattan.

Timera, M. (2014) 'Mots et maux de la migration. De l'anathème aux éloges', Cahiers d'Études Africaines 213-14 (1): 27-47.

Zimmerman, S. (2011) 'Living beyond boundaries: West African servicemen in French colonial conflicts, 1908-1962'. PhD thesis, University of California, Berkeley. 


\title{
Press sources
}

Le Soleil, 2004-12.

Agence de Presse sénégalaise (APS), 2004-12.

\section{Audiovisual sources \\ Music}

Awadi, D. (2010) Présidents d'Afrique. Studio Sankara.

Awadi, D. (2007) Un autre monde est possible. Tree Records.

\section{Film}

Sembène, O. and T. F. Sow (2003 [1988]) Camp de Thiaroye. Paris: Médiathèque des Trois Mondes.

Sembène, O. (2003 [1971]) Emitaï. Paris: Médiathèque des Trois Mondes.

Touré, M. (2012) La pirogue. Paris: Rezo Film and Studio 37.

\section{Interviews}

Pupils at the Lycée Seydou Nourou Tall, Pikine, focus group, July 2012.

Fippu Clan, rap group, Thiaroye-sur-Mer, February 2011.

Koné Mamadou, historian working in the Armed Forces Museum, interview in a focus group with Colonel Thioune and Colonel Manga, official at the Armed Forces Museum, Dakar, March 2011.

Iba, manager of the rap group Carapine Thiaroye 44, Thiaroye-sur-Mer, February 2011.

\begin{abstract}
This article is an attempt to reconsider the representations that, in Senegal in the 2000s, linked the social history of the tirailleurs (African colonial soldiers) with the practical and symbolic processes at the heart of a number of migratory projects, especially among young people. The history of this social military body was rooted in almost a century of colonial domination, from 1857 to 1962 . The tirailleurs played a part in all the battles of the French army and generated different kinds of social imaginaries that were woven between France and Africa. In the late 1950s, another figure, another ideal type, became established in the Senegalese public space: the migrant. After tracing the history of the way in which these two figures were constructed, I trace how, more recently, the younger generation has been able to mobilize the dominant memory of the tirailleur in its own aspirations of exile. Some preliminary methodological proposals will be needed to account for these migratory imaginaries.
\end{abstract}

\section{Résumé}

Cet article entend revenir sur les représentations qui ont conduit à lier, au Sénégal dans les années 2000, l'histoire sociale des tirailleurs avec des dynamiques, pratiques et symboliques, au cœur d'un certain nombre de projets migratoires, notamment parmi la jeunesse. L'histoire de ce corps social militaire s'enracine pendant 
presque un siècle de domination coloniale, de 1857 à 1962. Les tirailleurs ont ainsi été de tous les combats de l'armée française et ont généré différents imaginaires sociaux entremêlés entre la France et l'Afrique. À la fin des années 1950, une autre figure, un autre idéal-type, s'est imposé dans l'espace public sénégalais : le migrant. Après avoir tracé une histoire de la construction de ces deux figures, il s'agit de suivre comment, plus récemment, la jeunesse a pu mobiliser la mémoire dominante du tirailleur dans ses aspirations à l'exil. Il convient alors d'aborder quelques propositions d'ordre méthodologique pour rendre compte de ces imaginaires migratoires. 